\title{
House Prices and Marriage in Spain
}

\author{
Rafael González-Val 1,2 (iD
}

1 Facultad de Economía y Empresa (Campus Paraíso), Universidad de Zaragoza, c/Gran Vía 2, 50005 Zaragoza, Spain; rafaelg@unizar.es

2 Institut d'Economia de Barcelona (IEB), Facultat d'Economia i Empresa, Universitat de Barcelona, c/John M. Keynes, 1-11, 08034 Barcelona, Spain

\begin{abstract}
The aim of this study is to examine the link between house prices and marriage in Spain. We consider data from 50 Spanish provinces (NUTS III regions) and from local civil registries in 282 cities with populations greater than 25,000 inhabitants. The regional data cover the 1995-2018 period, whereas the local sample includes information from 2005 to 2018 . The marriage rate is defined as the annual absolute number of marriages per thousand inhabitants in each region or city. We used data on Spain because the Spanish housing market experienced a strong rise in house prices until 2006, when the housing bubble ended and prices dramatically decreased. By using different econometric techniques (panel data models with fixed effects and dynamic panel data models), our results reveal that there is a significant negative relationship between house prices and the marriage rate at both the regional and local levels. Overall, this study highlights the important consequences of rising house prices on family formations. Therefore, public authorities should try to reduce fluctuations in house prices and to facilitate access to home ownership for young couples.
\end{abstract}

Keywords: marriage; house prices; panel data models

check for

updates

Citation: González-Val, R. House Prices and Marriage in Spain.

Sustainability 2022, 14, 2848.

https://doi.org/10.3390/su14052848

Academic Editors: Pierfrancesco De

Paola and Maria Rosa Trovato

Received: 30 December 2021

Accepted: 28 February 2022

Published: 1 March 2022

Publisher's Note: MDPI stays neutral with regard to jurisdictional claims in published maps and institutional affiliations.

Copyright: (c) 2022 by the author. Licensee MDPI, Basel, Switzerland. This article is an open access article distributed under the terms and conditions of the Creative Commons Attribution (CC BY) license (https:// creativecommons.org/licenses/by/ $4.0 /)$.

\section{Introduction}

One strong concern in Western Europe in recent decades has been a slowdown in family formation and the subsequent changes in fertility rates. As Gholipour and Farzanegan [1] explained, the increasing marriage age due to rising economic and financial costs of family formation is one of the major drivers of lower fertility rates, even in countries in which there are no cultural or social prejudices against unmarried cohabitation. The consequences of these major demographic trends not only cast some doubts in the short term and midterm about the financial sustainability of social security systems and the provision of public goods, but they also challenge the future of our societies in the long term. Moreover, in addition to reproduction, marital status affects decisions regarding labor supply, consumption, reproduction, and other important matters [2]; thus, the determinants of marriage have strong policy implications.

It is well established in the literature that the creation of a family and its timing may crucially depend on certain economic variables. Gary Becker [3] established the foundations of the economics of the family decades ago, with a novel theoretical framework based on an economic approach. His theory was based on utility maximization, in that individuals choose to marry when the expected lifetime utility derived from marriage exceeds the expected utility from remaining single. From this perspective, changes (especially unexpected changes) in some economic factors, such as unemployment, labor supply, price stability and consumption, can affect family formation. An alternative viewpoint considers marriage as insurance against poor economic conditions [4,5]; thus, economic crises, unemployment, or a decrease in house prices could result in an increase in marriages. Furthermore, the Pereira-Grossbard model [6] analyzes the role played by savings in the probability of getting married. One of the reasons people save is to purchase housing, and in many cultures that follow traditional gender roles, men are encouraged to acquire 
housing in order to qualify for marriage. Therefore, rises in house prices would imply that more savings are needed in preparation for marriage, thus decreasing its probability.

To illustrate these arguments, Figure 1 shows the evolution of the marriage rate (number of marriages per 1000 of the population) in Spain at the national level. The average marriage rate remained stable until the year 2005; subsequently, the marriage rate continuously decreased until 2011, when it restabilized but at an average value substantially lower than that of the pre-2005 period. A key issue that could have affected marriages was the approval of the so-called 'express divorce law' in 2005, introducing unilateral divorce in Spain. Although the effect of unilateral divorce law reforms on marriages can be nonsignificant, or even positive (through the 'selection of marriages' hypothesis [7]), in Spain, the decline in marriages after the approval of the divorce law reform is clear. During the same period, the fertility rate (not shown) dropped dramatically, reaching the lowest level in the world [8].

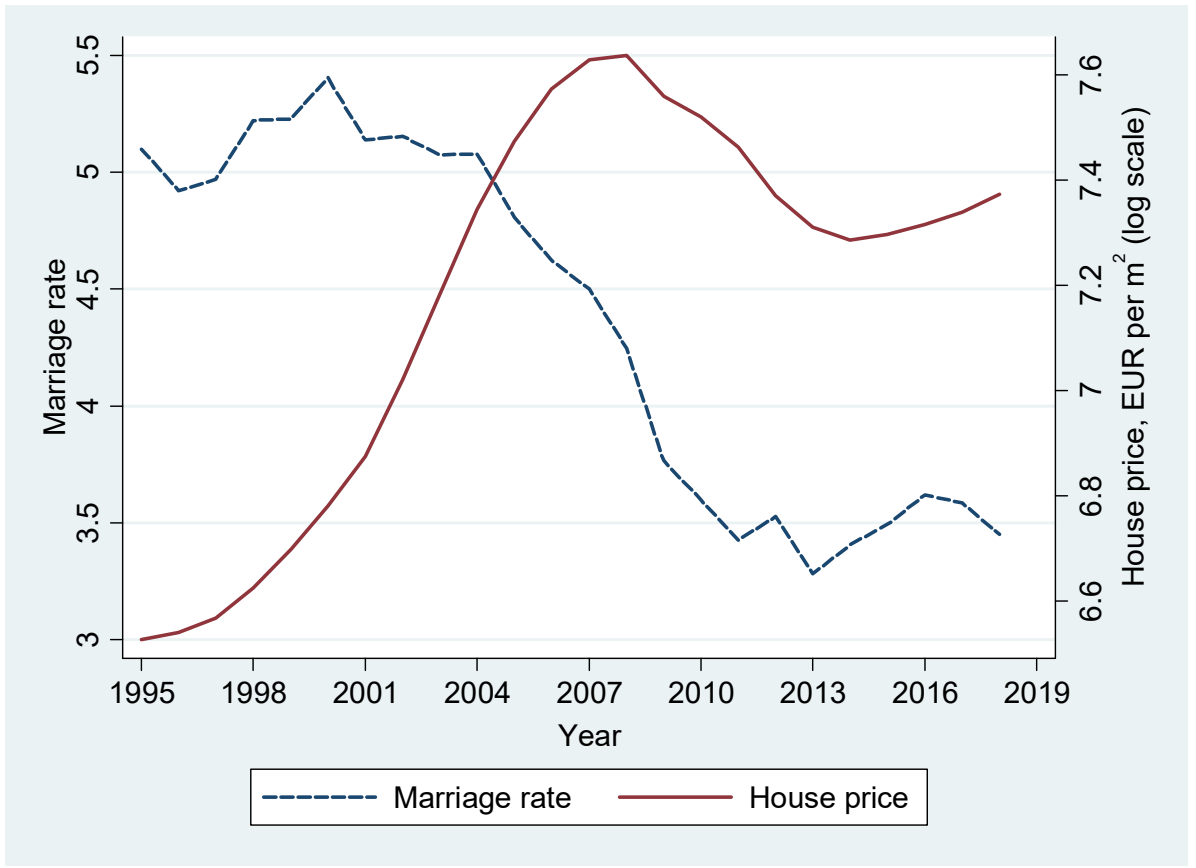

Figure 1. Marriage rate and house prices in Spain, 1995-2018. The marriage rate is the number of marriages per 1000 inhabitants and house prices are new house prices measured in EUR per $\mathrm{m}^{2}$.

The average house price is also plotted. Its evolution illustrates the recent Spanish housing boom. As Parreño Castellano et al. [9] explain, "between 1996 and 20076.5 million new residences were built in Spain [10], while average prices grew by 135\%." This extraordinary boom multiplied house prices more than threefold [11]. In particular, between 1995 and 2007, the annual rate of increase in house prices was $9.7 \%$ on average, with a maximum of over 17\% in 2003 and 2004. After 2008, during the Great Recession, house prices dramatically decreased. Notably, from 2008, both variables, marriage rates and house prices, seemed to perform similarly. This would suggest a relationship between house prices and marriage rates, although this is only descriptive evidence at the national level. The aim of this paper is to empirically investigate the link between house prices and marriage in Spain using aggregate data at different levels (regional and city-level data).

Challenges in estimating the effect of house prices on marriage using aggregate data are the possible omitted variable bias and endogeneity concerns. To deal with these potential issues, we estimated panel data models using the OLS and GMM estimators, including a set of additional variables to control for other relevant factors that may be influencing marriages. Furthermore, several robustness checks considering different subsamples were 
carried out. These methods allow us to obtain a significant and robust link between marriages and house prices, with important policy implications.

The remainder of the paper is organized as follows. Section 2 reviews the literature, presents the data used, and describes the theoretical model and the empirical methodology. Section 3 shows the main results, which are discussed in Section 4, and Section 5 concludes this study.

\section{Materials and Methods}

\subsection{Literature Review}

Most of the classical literature has focused on the relationship between unemployment and marriage, concluding that marriage rates are pro-cyclical [12-14]. Economic crises raise unemployment; therefore, it is natural to put the focus of attention on the relationship between marriage and unemployment. Nevertheless, economic crises usually have effects on many other markets besides the labor market, affecting the price and the provision of public and private goods that are crucial for marriage. One example of this is the housing market, because marriage usually involves at least two people living together in the same household (although living in the same household does not require marriage, and more than one family can live in the same household). Therefore, housing can be classified as a necessity [15] and, in many cases, is the main asset of the family.

There are some cross-country and time-series studies on the economic determinants of marriage and household formation (including housing prices). For the United States (US), it has been found that household formation is highly responsive to housing prices [16], with important implications for public policy, especially for low-income couples [17]. Recent studies focus on China, because housing is considered as a prerequisite for marriage and rising house prices in past years have made housing less affordable. These studies provide evidence of a negative effect of house prices on marriage $[18,19]$, with important socioeconomic consequences, such as welfare loss for young adults who want to enter marriage but cannot afford housing, or the financial constraints caused by high house prices. From a general perspective, housing market circumstances significantly affect the manner in which young people leave home as well as their age at departure [20], and in this case, marriage is an additional factor that increases the probability of living apart from parents through both increased potential earnings and increased demand for privacy [21].

The aim of these studies is to analyze the effects of housing market conditions (i.e., housing cost) on marriage. This differs from another strand of the literature that studies a related question: the influence of the homeownership status on marriage. In this related literature, there is strong evidence for a positive relationship between union formation (and especially marriage) and the transition to homeownership in different countries (e.g., the United States, The Netherlands, Australia, France, and West Germany) [22-28].

However, all of these studies consider microdata, and, to the best of our knowledge, only two have examined the link between house prices and marriage using panel data from a sample of a country's provinces $[1,29]$. This aggregate perspective seems vital, because, in many countries, housing markets and policies have strong regional features. Gholipour and Farzanegan [1] considered a panel of provinces of Iran over a period of nine years (2002-2010) to apply the generalized method of moments (GMM) estimator, and found a negative relationship between housing costs and the marriage rate. Su et al. [29] reviewed the threshold effect of house prices on marriage in 31 provinces of China, utilizing a panel threshold regression. Nevertheless, both Iran and China are particular cases with very specific idiosyncrasies (a Muslim-dominant and communist country, respectively); therefore, these results cannot easily be extrapolated to other countries, especially if there are important cultural differences (which also imply different gender roles). Many cultures following traditional gender roles have encouraged men to acquire housing in order to qualify for marriage, and Grossbard [6] pointed out that this expectation was historically more prevalent in Italy than in other Western countries. The Spanish case should be similar 
to the Italian case, because both countries share important similarities, including important Catholic traditions.

We contribute to this literature in three ways. First, we examine the Spanish case, so our results could help in understanding the dynamics in other European countries facing similar scenarios. In fact, the declining trend in marriage rates over recent decades observed in Spain is a common trend in most European countries. Second, the Spanish situation is especially interesting from the housing market perspective because, during the period considered, the market experienced a spectacular boom followed by a dramatic collapse of the housing bubble; from 2008 onwards, prices fell for six years in a row [30]. Thus, our data provide strong variations in house prices over time. Third, we consider aggregate data at the regional level, but also a dataset at the city level, a more disaggregated spatial unit that can provide greater accuracy in measuring the evolution of house prices and, therefore, a more robust estimate of the relationship between house prices and marriage. The data from all the Spanish provinces cover the whole territory and population of the country, whereas data from local civil registries located in the largest cities provide a different sample exclusively focused on the urban environment.

\subsection{Data}

We considered two different spatial units: 50 Spanish provinces (in terms of the European Union's standard classification of European regions, 'Nomenclature des unités territoriales statistiques', the NUTS 3 regions) and 282 cities (i.e., municipalities, the LAU 2/NUTS 5 regions) with a population greater than 25,000 inhabitants. In both cases, the marriage rate is defined as the annual absolute number of marriages per thousand inhabitants in each region or city. The marriage dataset covers the period 1995 to 2018 (Instituto Nacional de Estadística, INE). At the city level, marriage data come from the municipal civil registries. Although the INE provides marriage data for all municipalities in Spain, we only considered the 282 largest cities, because house price data at the city level are only available for the largest cities, which account for $65 \%$ of total marriages in the country.

House prices are new house prices measured in EUR per $\mathrm{m}^{2}$ (Ministerio de Fomento, Spanish Government). Regional house prices are available for the period considered (1995-2018), but local prices have only been available since 2005, which restricted our local sample to the 2005-2018 period. We do not include rentals in our analysis, because Spaniards show a strong preference for property ownership as opposed to renting. As Blanco et al. [11] indicate, "in Spain, property ownership is widely viewed as superior to renting almost as a social status". As a result, the rental market in Spain is far less developed than in other European countries. According to Eurostat data, the owner-occupancy rate in 2018 was 76.3\%, higher than the average value for the European Union (69\%), whereas according to the INE's Continuous Household Survey, the rental share was $17.8 \%$. Thus, given that the proportion of renters is much lower than that of owners in Spain, and the lack of official data on housing rents, we exclusively focus on owners in this study.

The spatial scale is an important issue. Figure 2 plots marriage rates over time by region, and significant differences across regions can be observed relative to the country average value (represented by the thick black dashed line). This regional variation increases even more when we consider house prices, as Figure 3 shows. Blanco et al. [11] studied the existence of convergence clusters among Spanish regions on the basis of house price trends from 1995 to 2007, concluding that some degree of segmentation in the Spanish housing market exists. For instance, their results confirm that the housing boom was much more pronounced in coastal provinces, mainly on the Mediterranean coast. These considerable differences point to the necessity of a regional analysis of the impact of house prices on marriage. 


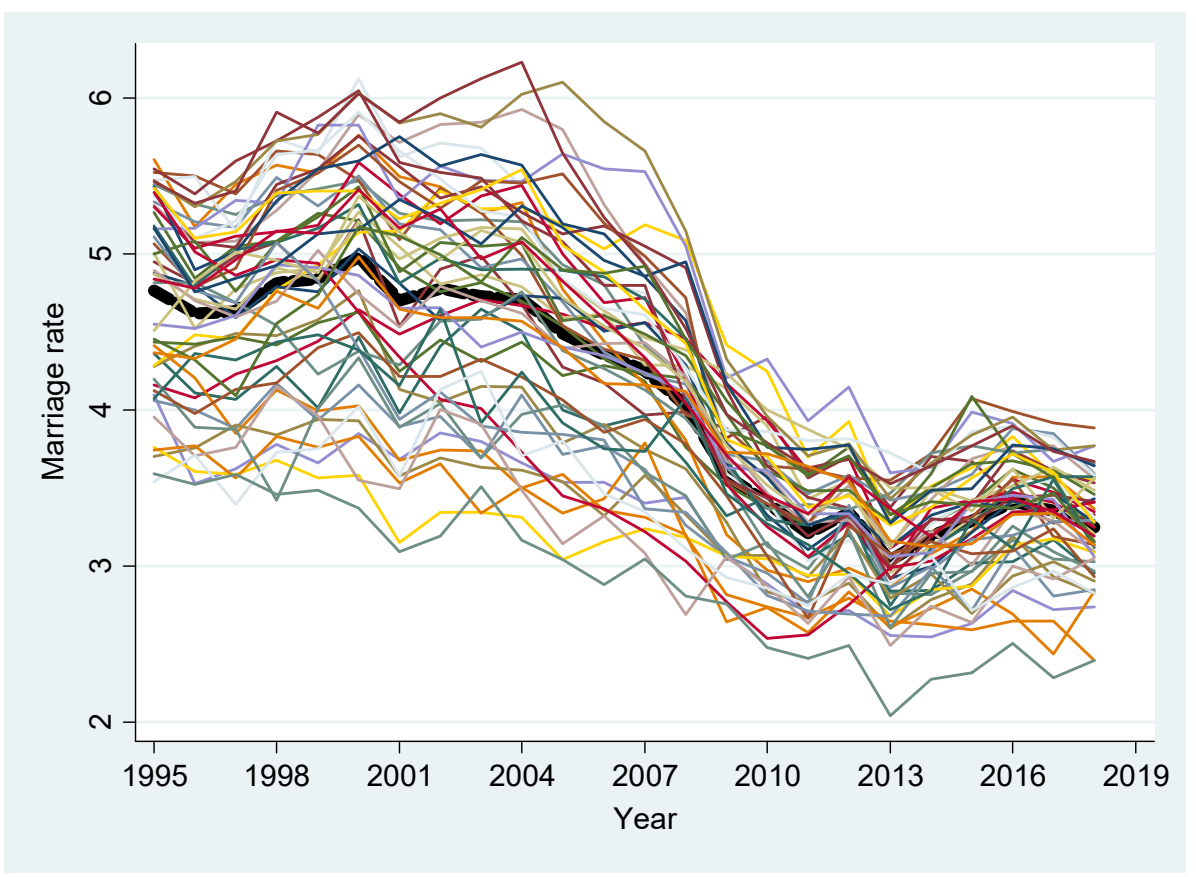

Figure 2. Marriage rate by region, 1995-2018. The marriage rate is the number of marriages per 1000 inhabitants. The thick black line is the country's average value.

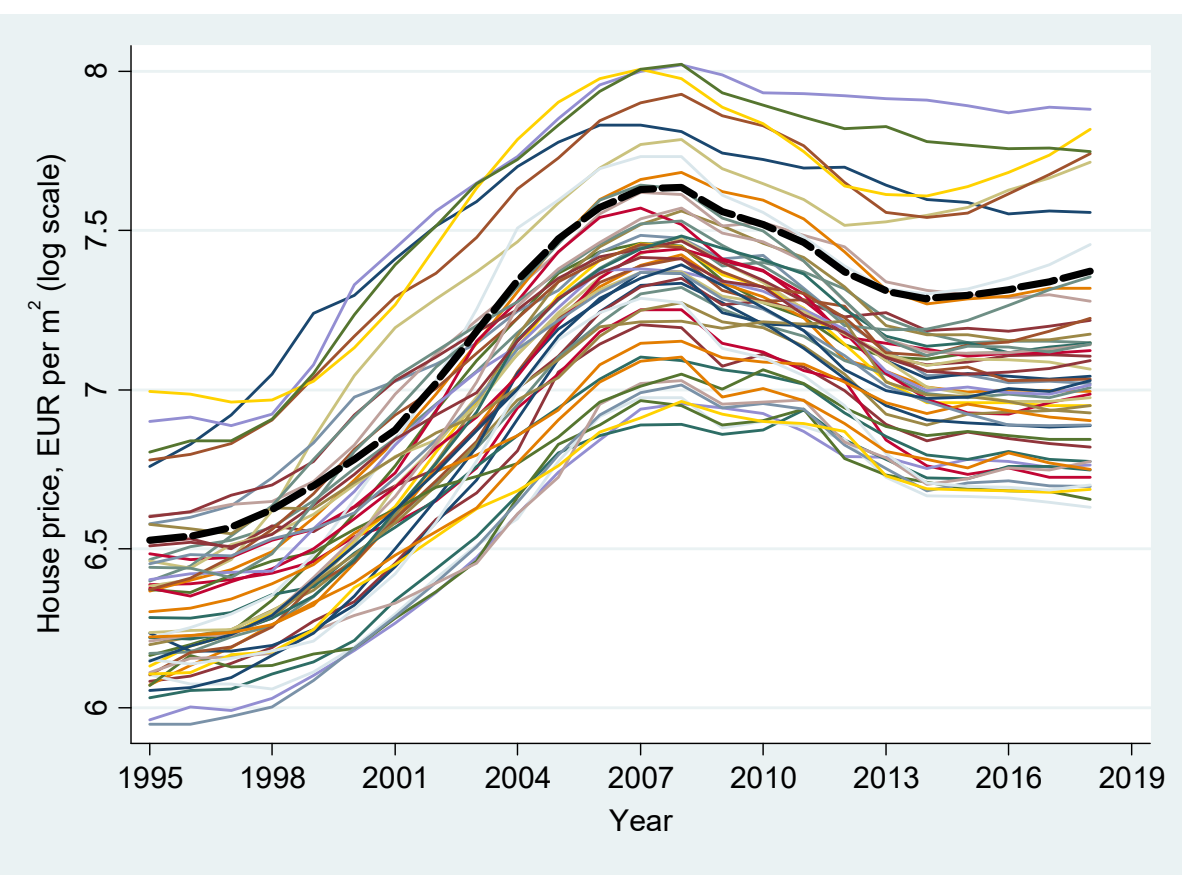

Figure 3. House prices by region, 1995-2018. House prices are new house prices measured in EUR per $\mathrm{m}^{2}$. The thick black line is the country's average value.

Table 1 shows the average marriage rate and house price by year for regions and cities over the period considered. These values highlight the differences between the two samples. Although the temporal evolution of marriage rates is similar in both spatial units, levels are clearly higher at the local level. Regarding house prices, the regional data consist of huge geographical areas, including both rural and urban areas; thus, the average house price measure is an average of all the cities within the region. Therefore, house prices in large cities tend to be higher than regional prices in most cases, better capturing the market boom and the subsequent crashes. 
Table 1. Average marriage rate and house price.

\begin{tabular}{|c|c|c|c|c|}
\hline \multirow[b]{2}{*}{ Year } & \multicolumn{2}{|c|}{ Regional Data } & \multicolumn{2}{|c|}{ Local Data } \\
\hline & Marriage Rate & House Price & Marriage Rate & House Price \\
\hline 1995 & 4.77 & 581.60 & & \\
\hline 1996 & 4.62 & 591.37 & & \\
\hline 1997 & 4.63 & 604.27 & & \\
\hline 1998 & 4.81 & 637.15 & & \\
\hline 1999 & 4.84 & 697.38 & & \\
\hline 2000 & 4.98 & 782.21 & & \\
\hline 2001 & 4.70 & 877.42 & & \\
\hline 2002 & 4.78 & 984.78 & & \\
\hline 2003 & 4.73 & 1108.66 & & \\
\hline 2004 & 4.71 & 1271.78 & & \\
\hline 2005 & 4.49 & 1439.82 & 4.98 & 1785.15 \\
\hline 2006 & 4.35 & 1598.26 & 4.80 & 1986.84 \\
\hline 2007 & 4.25 & 1690.56 & 4.68 & 2135.71 \\
\hline 2008 & 4.03 & 1705.13 & 4.34 & 2119.42 \\
\hline 2009 & 3.58 & 1581.79 & 3.82 & 1903.18 \\
\hline 2010 & 3.40 & 1538.93 & 3.59 & 1792.34 \\
\hline 2011 & 3.21 & 1468.96 & 3.42 & 1660.82 \\
\hline 2012 & 3.34 & 1361.19 & 3.52 & 1514.77 \\
\hline 2013 & 3.03 & 1260.83 & 3.26 & 1335.25 \\
\hline 2014 & 3.20 & 1213.63 & 3.44 & 1221.03 \\
\hline 2015 & 3.29 & 1216.32 & 3.58 & 1204.55 \\
\hline 2016 & 3.41 & 1220.50 & 3.75 & 1209.07 \\
\hline 2017 & 3.35 & 1230.06 & 3.72 & 1248.82 \\
\hline 2018 & 3.25 & 1247.09 & 3.58 & 1325.80 \\
\hline
\end{tabular}

Note: Marriage rate is the number of marriages per 1000 population. House prices in EUR per $\mathrm{m}^{2}$.

\subsection{Theoretical Model}

There are several theoretical models explaining the potential relationship between house prices and marriage. Here, we follow the duration model [29,31-33]. Rising house prices can have a negative effect on marriage, which is in line with the budget constraint on household consumption. In this model, the household faces a tradeoff between marriage and consumption, and utility is the basic motive determining whether individuals marry. When the combined utility of both partners exceeds their individual utility levels, the individuals choose to marry. Nevertheless, the transition from being single to becoming a married couple requires several direct expenses, among which one of the most important is buying a house. This way, rising house prices can delay or reduce the decision to marry.

Individuals maximize utility by having a budget constraint and deciding to allocate their income on consumption and marriage; marriage is assumed to be a normal good. Thus, the maximization problem for an individual is as follows:

$$
\operatorname{Max} U(M A R, C) \text { s.t. } P_{M A R}+P_{H P} H(M A R)+C=I
$$

where MAR indicates marriage, $C$ represents the consumption of a numeraire good, $H(M A R)$ is the demand for housing, and I denotes income. The price of the numeraire good is normalized to 1 and $P_{M A R}$ and $P_{H P}$ are the prices for marriage and housing, respectively. Housing is imperative for marriage; therefore, it is included as a budget constraint, and $H^{\prime}=\frac{d H}{d M A R}$ is positive because housing demand is an increasing function of marriage.

It is assumed that utility is increasing in consumption and marriage: $U_{M A R}>0$ and $U_{C}>0$. Moreover, marginal utility is assessed across marriage and consumption: $U_{M A R, C}>0$. The first-order conditions are:

$$
\begin{gathered}
U_{M A R}\left(M A R^{*}, C^{*}\right)+\lambda\left(-P_{M A R}-P_{H P} H^{\prime}\right)=0 \\
U_{C}\left(M A R^{*}, C^{*}\right)-\lambda=0
\end{gathered}
$$


where the Lagrange multiplier $\lambda$ indicates the marginal utility of income. From Equation (2), we can derive $\frac{U_{M A R}}{\lambda}=P_{M A R}+P_{H P} H^{\prime}$, which is the shadow price of marriage. $H^{\prime}>0$; therefore, the shadow price of marriage increases as house prices increase. By manipulating the first-order conditions of the maximization problem, we can derive the comparative statistics of marriage at the optimum with respect to the price of the house as:

$$
\frac{d M A R}{d P_{H P}}=\frac{\left[-\lambda H^{\prime}+H\left(M A R^{*}\right) \cdot\left(-U_{M A R, C}+\left(P_{M A R}+P_{H P} H^{\prime}\right) U_{C, C}\right)\right]}{\left[-U_{M A R, M A R}+U_{M A R, C}\left(P_{M A R}+P_{H P} H^{\prime}\right)\right]}
$$

where $U_{M A R, C}>0, U_{M A R, M A R}<0, U_{C, C}<0, \lambda>0$. It is easy to show that the sign of the derivative is negative: $\frac{d M A R}{d P_{H P}}<0$. Therefore, house price has a negative impact on marriage through income and compensated substitution effects. The compensated substitution effect reveals that variations in housing demand change marriage because the house price is part of the shadow price of marriage. An increase in house prices causes a reduction in the demand for housing, which may lead to a decrease in marriage. The derivative also includes a negative income effect: expenditures on housing increase with the rise in the house price, which makes the budget more constrained (we assumed that marriage is a normal good that decreases with higher house prices).

In aggregate terms, the implication of the model is that rising house prices can delay or reduce the marriage rate. Therefore, we can expect that expensive housing markets, such as those observed during the housing boom in Spain before the year 2008, could encourage people to delay their marriages, whereas the sharp drop in house prices after the crash of the housing bubble could facilitate new marriages.

A similar conclusion can be reached using alternative theoretical approaches. For instance, in terms of the Pereira-Grossbard model [6], a rising house price would indicate the need for more saving in preparation for marriage, and thus, a decrease in the probability of marriage (or an equivalent decrease in the marriage rate, in aggregate terms). Gholipour and Farzanegan [1] used the formulation of the Easterlin hypothesis [34] provided by Hughes [35]: "Young adults measure their income and their economic readiness (including home ownership) for marriage against their material aspirations"; therefore, "if young adults are able to achieve home ownership (which is an important marker of economic security and future economic well-being) and income is high relative to aspirations, then it will be easier to marry sooner and have more children".

\subsection{Empirical Models}

Empirically, our strategy follows Gholipour and Farzanegan [1]. First, we estimate the following equation:

$$
M A R_{i t}=\alpha+\beta_{1} \cdot \ln \left(H P_{i t}\right)+\beta_{2} \cdot U N E M P_{i t}+\beta_{3} \cdot I N F_{i t}+\beta_{4} \cdot E D U_{i t}+\beta_{5} \cdot W E A_{i t}+v_{i}+\Omega_{t}+u_{i t}
$$

where $M A R_{i t}$ is the marriage rate in a region (or city) $i$ at time $t$. The main explicative variable is $\ln \left(H P_{i t}\right)$, the logarithm of the house price. Then, the sign of the $\beta_{1}$ coefficient captures the positive or negative response of marriage rates to changes in house prices.

Following existing studies on marriage and household formation, we selected a set of additional factors to avoid omitted variable bias. These explanatory variables are the unemployment $\left(U N E M P_{i t}\right)$ and inflation $\left(I N F_{i t}\right)$ rates and the percentage of the female population with some college $\left(E D U_{i t}\right)$. The descriptive statistics of these variables are shown in the Appendix A.

Both unemployment and inflation are related to the standard of living. The theoretical approach indicates that the economic constraints generated by a job loss and/or the lower economic expectations during an economic recession period are associated with lower probabilities of engaging in marriage. González-Val and Marcén [36] found a negative effect of unemployment on marriage rates in Spain, especially after the year 2005. Unemployment data come from the Spanish Labour Force Survey. Regarding inflation, it can have a substantial negative effect on the decision to marry; high inflation can influence marriage 
by creating economic uncertainty [37]. Spain reports consistently higher inflation rates than other European Union (EU) countries. Lopez and Papell [38] studied the behavior of inflation rates among several EU countries in recent decades, and found that until 2008, Spain was one of the countries reporting the highest inflation rates in Europe; Spain was then one of the countries most affected by the 2008 crisis; and finally, after the crisis, Spain's inflation exhibited a moderate decrease. Our measure of the inflation rate is the rate of change in the Consumer Price Index.

Several studies corroborate the effect of educational attainment of women on marriage, although this effect can be positive or negative (or even change over time from one to the other; see [39] for a study of the United States' case). For Spain, Gutiérrez-Domènech [40] found that highly educated married women delay the first birth and family formation. Thus, we included the percentage of female population 16 years and over with some college education or a higher degree.

The model also includes regional (or local) fixed effects $\left(v_{i}\right)$ to control for unobserved characteristics that can vary at the regional or local levels, and year fixed effects $\left(\Omega_{t}\right)$ that aim to capture year-specific determinants of marriage rates. $u_{i t}$ is the error term.

The panel data model proposed by Gholipour and Farzanegan [1] is extended here in two ways. First, we added a set of weather controls by region $\left(W E A_{i t}\right)$, because previous research [36] found a significant influence of geography on the formation and stability of Spanish couples (especially on the pattern of divorce rates). González-Val and Marcén [36] offer some explanations for this spatial pattern: weather conditions can be responsible, to some extent, for possible social interactions, because weather conditions may impact both mood and prosocial behavior [41]. They argue that the better the weather conditions, the greater the possibility of meeting and matching with more potential partners, because individuals spend more time outside, increasing the number of social interactions. Moreover, as mentioned above, Blanco et al. [11] found that the housing boom was much more pronounced in coastal provinces, mainly on the Mediterranean coast. Therefore, the region's (or city's) spatial location may have an effect on both marriage rates and house prices, which are our endogenous and main explicative variables, respectively. Thus, if controls for weather conditions are not added, results can be biased. Taking this into account, we added the following weather controls to the specification: the annual average precipitation, the annual number of cloudless days, the annual average temperature, the annual number of days with temperatures greater than $25^{\circ} \mathrm{C}$, and the annual number of days with temperatures below $0{ }^{\circ} \mathrm{C}$, all measured at the regional level (data from the INE). Moreover, as a robustness check, in some specifications, we separated the inland and coastal regions to look for differentiated behaviors.

Second, we also estimate model (4) considering data at the city level of the largest cities in the country, a spatial unit more disaggregated than regions. Taking advantage of the local data of marriages and house prices would, supposedly, enable more accurate estimates of the relationship between house prices and marriage because the house price at the regional level is the average of all the cities and rural areas within the region.

We estimated the model (4) by OLS, with robust standard errors clustered by region (or city). Although we included fixed effects and time fixed effects to control for possible unobserved characteristics at the regional (or city) level and year-specific shocks, some potential issues still remain. These include the possible persistence in the trend in the dependent variable (marriage rates), related to dynamic issues of the variable, and endogeneity concerns and reverse causality. To solve both potential issues, Gholipour and Farzanegan [1] recommended adding one lag of the marriage rate on the right-hand side of the model and estimating by using the GMM estimator. Thus, model (4) turns into a dynamic panel model:

$$
M A R_{i t}=\alpha+\beta_{1} \cdot \ln \left(H P_{i t}\right)+\beta_{2} \cdot U N E M P_{i t}+\beta_{3} \cdot I N F_{i t}+\beta_{4} \cdot E D U_{i t}+\beta_{5} \cdot W E A_{i t}+\beta_{5} \cdot M A R_{i t-1}+v_{i}+\Omega_{t}+u_{i t}
$$

Resembling the work of Gholipour and Farzanegan [1], we used the difference GMM estimator developed by Arellano and Bond [42]. By using a first differencing transforma- 
tion, individual specific unobserved effects were eliminated and the effects of possible time trends in our main variables of interest were also controlled. After the first-differencing model (5), the equation was estimated via GMM. The independent variables were instrumented with lagged values of the dependent and independent variables. In our case, we used lags 1-2 of all the explanatory variables and of the dependent variable as instruments.

\section{Results}

\subsection{Regional Results}

For illustrative purposes, Figure 4 shows the bivariate relationship between the marriage rate and house prices at the regional level. We observed a clear negative relationship. The higher the house price, the lower the marriage rate, although observations displayed a great variance. However, this is just the unconditional relationship.

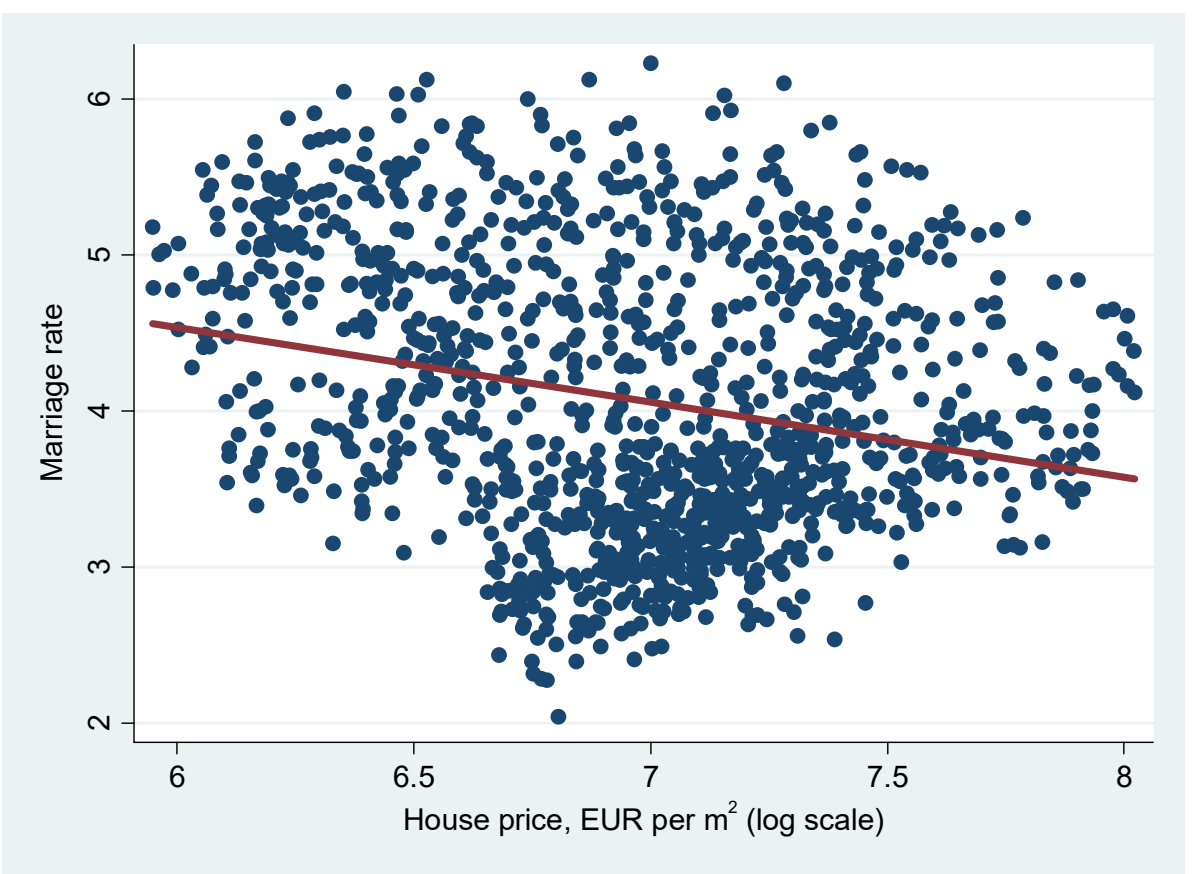

Figure 4. Marriage rates and regional house prices, 1995-2018. The marriage rate is the number of marriages per 1000 inhabitants and house prices are new house prices measured in EUR per $\mathrm{m}^{2}$.

Table 2 reports the estimates of Equation (4) for regional data. As seen in the first column, which does not include any controls, the estimated coefficient capturing the effect of the regional house prices is negative and significant, which is in line with Figure 4 (the coefficient is the slope of the line fitted in the figure). In columns (2) and (3), we included weather controls and regional and year fixed effects. We also added the set of controls for macroeconomic indicators. This set of macroeconomic variables was included to control for observable differences across regions and to avoid omitted variable bias. After the inclusion of all these controls, the coefficients picking up the effect of house prices remained negative and significant, and the magnitude of the coefficient increased. Consistent with González-Val and Marcén [36], the impact of unemployment was negative and significant, pointing to a pro-cyclical behavior of the Spanish marriage rate, whereas the inflation rate had a positive and significant coefficient, and female education had a negative but non-significant effect on marriage. 
Table 2. Regional marriage rate models, 1995-2018.

\begin{tabular}{lccc}
\hline & $\mathbf{( 1 )}$ & $\mathbf{( 2 )}$ & $\mathbf{( 3 )}$ \\
\hline $\ln$ (House price) & $-0.481^{* * * *}$ & $-0.488^{* * *}$ & $-0.525^{* * *}$ \\
Unemployment rate & $(0.114)$ & $(0.125)$ & $(0.182)$ \\
& & $-0.043^{* * *}$ & $-0.038^{* * *}$ \\
Inflation rate & & $(0.007)$ & $(0.006)$ \\
& & $0.169^{* * *}$ & $0.091^{* * *}$ \\
\% female population with some college & & $(0.016)$ & $(0.037)$ \\
Weather controls & & -0.004 & -0.005 \\
Regional fixed effects & $\mathrm{N}$ & $(0.009)$ & $(0.005)$ \\
Year fixed effects & $\mathrm{N}$ & $\mathrm{Y}$ & $\mathrm{Y}$ \\
\hline $\mathrm{R}^{2}$ & $\mathrm{~N}$ & $\mathrm{~N}$ & $\mathrm{Y}$ \\
Mean VIF & 0.058 & 0.408 & $\mathrm{Y}$ \\
Observations & 1.000 & 2.500 & 0.914 \\
\hline
\end{tabular}

Notes: Dependent variable: marriage rate. All the models included a constant. Robust standard errors clustered by region. Significant at the ${ }^{*} 10 \%, * * 5 \%,{ }^{* * *} 1 \%$ levels. Weather controls: annual average precipitation, annual number of cloudless days, annual average temperature, annual number of days with temperatures greater than $25^{\circ} \mathrm{C}$, annual number of days with temperature lower than $0{ }^{\circ} \mathrm{C}$, measured at the province level.

We also estimated the dynamic model (5) by using the difference GMM estimator. These results are shown in Table 3. This time, we show only the results of the estimation including all the controls (Column 1). We obtained a positive and significant coefficient for the past marriage rate, supporting persistence and a dynamic behavior of the variable. The effect of house prices remained negative and significant, although the magnitude of the coefficient was greater than that of the OLS fixed effects model (last column in Table 2). Regarding the rest of the controls, the only significant coefficient was that of the unemployment rate, which remained negative and significant. The effects of both the inflation rate and the female education variables were not significant.

Table 3. Regional marriage rate models, difference GMM.

\begin{tabular}{|c|c|c|c|c|}
\hline & All Regions & $\begin{array}{c}\text { Excluding Barcelona and } \\
\text { Madrid }\end{array}$ & $\begin{array}{l}\text { Coastal } \\
\text { Regions }\end{array}$ & $\begin{array}{l}\text { Inland } \\
\text { Regions }\end{array}$ \\
\hline & (1) & (2) & (3) & (4) \\
\hline Marriage rate $\mathrm{t}-1$ & $\begin{array}{c}0.617^{* * *} \\
(0.044)\end{array}$ & $\begin{array}{c}0.632 * * * \\
(0.043)\end{array}$ & $\begin{array}{c}0.867^{* * *} \\
(0.034)\end{array}$ & $\begin{array}{c}0.559 * * * \\
(0.059)\end{array}$ \\
\hline $\ln$ (House price) & $\begin{array}{c}-0.846^{* * *} \\
(0.116)\end{array}$ & $\begin{array}{c}-0.800^{* * *} \\
(0.118)\end{array}$ & $\begin{array}{c}-0.523^{* * *} \\
(0.113)\end{array}$ & $\begin{array}{c}-0.362 \text { ** } \\
(0.162)\end{array}$ \\
\hline Unemployment rate & $\begin{array}{c}-0.011^{* * *} \\
(0.004)\end{array}$ & $\begin{array}{c}-0.010^{* *} \\
(0.004)\end{array}$ & $\begin{array}{l}-0.001 \\
(0.005)\end{array}$ & $\begin{array}{l}-0.006 \\
(0.004)\end{array}$ \\
\hline Inflation rate & $\begin{array}{c}0.029 \\
(0.021)\end{array}$ & $\begin{array}{c}0.031 \\
(0.022)\end{array}$ & $\begin{array}{c}0.008 \\
(0.024)\end{array}$ & $\begin{array}{l}0.042 * \\
(0.023)\end{array}$ \\
\hline \multirow{2}{*}{$\begin{array}{l}\% \text { female population } \\
\text { with some college }\end{array}$} & -0.003 & -0.003 & -0.004 & -0.002 \\
\hline & $(0.003)$ & $(0.003)$ & $(0.003)$ & $(0.002)$ \\
\hline Weather controls & $\mathrm{Y}$ & $\mathrm{Y}$ & $\mathrm{Y}$ & $\mathrm{Y}$ \\
\hline Year fixed effects & $\mathrm{Y}$ & $\mathrm{Y}$ & $\mathrm{Y}$ & $\mathrm{Y}$ \\
\hline $\mathrm{AR}(2), p$-value & 0.055 & 0.030 & 0.040 & 0.200 \\
\hline Hansen test, $p$-value & 0.999 & 0.999 & 0.999 & 0.999 \\
\hline Regions & 50 & 48 & 22 & 28 \\
\hline Observations & 1150 & 1104 & 506 & 644 \\
\hline
\end{tabular}

Notes: The difference GMM method was used to remove the cross-section fixed effect and to control for possible trends in data. As instruments, we used lags 1-2 of all the explanatory variables and of the dependent variable Robust standard errors. Significant at the ${ }^{*} 10 \%,{ }^{* *} 5 \%, * * 1 \%$ level. Weather controls: annual average precipitation, annual number of cloudless days, annual average temperature, annual number of days with temperatures greater than $25^{\circ} \mathrm{C}$, annual number of days with temperature lower than $0{ }^{\circ} \mathrm{C}$, measured at the province level. 
In the rest of the columns, we conducted several robustness checks considering different subsamples of the data. First, in Column 2, we removed Barcelona and Madrid from the sample (Gholipour and Farzanegan [1] carried out a similar robustness check, removing the Tehran province from the full sample of Iranian regions). The reason for removing Barcelona and Madrid was because their housing prices are much higher than in other provinces, so they could be considered outliers, and their removal may affect our findings. Nevertheless, results held similarly; thus, we conclude that the regions with higher house prices did not drive our results. In Columns 3 and 4, we split the sample into coastal and inland regions. This is because, in coastal regions, the housing boom in the early 2000s was stronger [11]. The results showed that, although in both types of region the effect was significant and negative (Columns 3 and 4), the estimated coefficient measuring the magnitude of the effect was greater for coastal regions than for inland regions, possibly as a consequence of the higher inflation in house prices on the coast.

Gholipour and Farzanegan [1], following Arellano and Bond [42], remarked on the importance of passing some tests to validate the use of the GMM estimator. In particular, this included the second-order (AR (2)) test for serial correlation in the first-differenced residuals proposed by Arellano and Bond [42] and the Hansen test for the validity of the instruments used. Table 3 reports the results for both tests; results of the Hansen test validate our instruments, and serial correlation was not found.

\subsection{Local Results}

Similar to the analysis of the marriage rate at the regional level, we now consider marriage and house price data at the local level. As mentioned above, house prices at the city level are more accurate than averages at the region level. Moreover, changes in house prices were more intense in the more densely populated locations. Nevertheless, local house prices have only been available since 2005; therefore, we carried out the analysis using a shorter period, from 2005 to 2018. Additionally, macroeconomic indicators are not defined at the city level, so we used the regional values of the unemployment and inflation rates, the female education variable, and weather controls. This time, we only focused on the difference GMM estimations, because the OLS results were not conclusive.

Table 4 reports the estimated results for the dynamic model (5). We considered three different samples of cities: all cities with a population greater than 25,000 inhabitants (282 cities); the same sample of large cities excluding the two major cities in the country (280 cities), Madrid and Barcelona; and a third sample of 232 cities excluding all the capital cities (one per region). We considered these subsamples as a robustness check to avoid results being driven by the largest cities. Again, only the results of the estimation including all the controls were reported, and the three models passed the AR(2) and Hansen tests. The coefficient for the lagged marriage rate was positive and significant, supporting the dynamic model. The effect of house prices remained negative and significant in all cases, with an estimated coefficient consistent across samples with a negative value around 0.5. One interesting point is that the local effect of house prices on marriage was lower than that obtained with regional data in Table 3, indicating that, in large cities, where the ups and downs of house prices are sharper than the regional average, the relationship between house prices and marriage is weaker than that at the regional level. 
Table 4. Local marriage rate models, difference GMM.

\begin{tabular}{lccc}
\hline & All Cities & $\begin{array}{c}\text { Excluding Barcelona } \\
\text { and Madrid }\end{array}$ & $\begin{array}{c}\text { Excluding } \\
\text { Capital Cities }\end{array}$ \\
\hline Local marriage rate t-1 & $\mathbf{( 1 )}$ & $\mathbf{( 2 )}$ & $\mathbf{( 3 )}$ \\
ln(Local house price) & $0.166^{* * *}$ & $0.165^{* * *}$ & $0.177^{* * *}$ \\
& $(0.032)$ & $(0.032)$ & $(0.034)$ \\
Regional unemployment rate & $-0.487^{* *}$ & $-0.501^{* *}$ & $-0.550^{* *}$ \\
& $(0.225)$ & $(0.228)$ & $(0.235)$ \\
Regional inflation rate & $-0.057^{* * *}$ & $-0.057^{* * *}$ & $-0.058^{* * *}$ \\
& $(0.008)$ & $(0.008)$ & $(0.009)$ \\
Regional \% female population & 0.055 & 0.055 & $0.077^{*}$ \\
with some college & $(0.035)$ & $(0.035)$ & $(0.044)$ \\
& -0.003 & -0.003 & -0.004 \\
Regional weather controls & $(0.005)$ & $(0.005)$ & $(0.007)$ \\
Year fixed effects & $\mathrm{Y}$ & $\mathrm{Y}$ & $\mathrm{Y}$ \\
\hline AR(2), $p$-value & $\mathrm{Y}$ & $\mathrm{Y}$ & $\mathrm{Y}$ \\
Hansen test, $p$-value & 0.427 & 0.109 & 0.165 \\
Cities & 0.106 & 0.100 & 232 \\
Observations & 282 & 280 & 2778 \\
\hline
\end{tabular}

Notes: Dependent variable: marriage rate. Difference GMM method was used to remove the cross-section fixed effect and to control for possible trends in data. As instruments, we used lags 1-2 of all the explanatory variables and of the dependent variable. Robust standard errors. Significant at the $* 10 \%, * * 5 \%, * * * 1 \%$ levels. Weather controls: annual average precipitation, annual number of cloudless days, annual average temperature, annual number of days with temperatures greater than $25^{\circ} \mathrm{C}$, annual number of days with temperature lower than $0{ }^{\circ} \mathrm{C}$, measured at the province level.

Regarding the set of regional macroeconomic indicators and consistent with the regional results, the only significant (and negative) effect on marriage at the local level corresponded to the regional unemployment rate, confirming the pro-cyclical evolution of marriage [36].

\section{Discussion}

This study examined the relationship between variations in house prices and marriage rates. We used data from 50 Spanish provinces (NUTS 3 regions) and from local civil registries in 282 cities with a population greater than 25,000 inhabitants. The results showed a robust negative relationship between marriage rates and house prices in both datasets using the OLS and GMM estimators, which was consistent with the predictions of the duration model. Furthermore, these results held when we considered the different subsamples, i.e., excluding the two main regions/cities, splitting the sample between coastal and inland regions, and excluding all the capital cities.

In related research, a common result obtained in studies using microdata yielded a negative effect of rising house prices on the probability of marriage [16-21]. Consistently, the only two previous studies that tested the link between house prices and marriage considering aggregate data at the regional level $[1,29]$ also found a similar negative relationship for Iranian and Chinese provinces. Our results confirmed this negative link in the Spanish case, although the estimated coefficients obtained were lower than those reported by Gholipour and Farzanegan [1] for Iran. In the case of Chinese provinces, the negative impact of house prices on marriage was found only for high prices. Therefore, in comparison with the scarce previous evidence, in Spain, the relationship between house prices and marriage was stronger than that found in Chinese provinces, but the link was weaker than for Iranian regions. The explanation for these different results across countries may rely on the strong cultural, economic, and social differences.

Our results have strong policy implications, because there is a strong connection between the drop in marriages and the decline in fertility in Spain [8], which is an important 
social problem. Therefore, encouraging marriage could be one way to increase fertility. Our results revealed an economic variable that affects family formation, i.e., house price, which should be taken into account by policymakers. Furthermore, we also obtained a robust negative effect of unemployment on marriages, so an alternative way to facilitate marriage could be labor market policies aimed to reduce unemployment with a special target on youth (in the European Union, Spain has the second-highest percentage of young people who neither work nor study).

One way to encourage marriages could be to facilitate access to home ownership for young couples. This could be achieved by increasing the supply of public housing for lowincome people or introducing fiscal benefits for saving and mortgage loans. Nevertheless, there is a tradeoff in the demand-side policies. Easier access to the housing market would increase marriages, but at the same time, a rise in housing demand generates an increase in the house prices in the short run which, according to our results, would decrease the number of marriages.

Overall, the government should try to balance housing supply and demand with higher supervision to discourage private market monopolies [29]. This issue is especially relevant because new actors have appeared in the Spanish housing market in recent years [43,44]. Since 2013, and especially since 2017, agreements between the most important Spanish banks and foreign capital funds (such as BlackRock, Vanguard, Brookfield Asset Management, Cerberus, and Blackstone, among others) have facilitated the irruption of these private funds into the Spanish housing market. Today, 10 out of the 15 most important property developers in the country are controlled by foreign funds (mostly American). The increasing market power of these funds in the Spanish housing market could be generating negative effects on family formation if this loss of competition in the market raises house prices.

\section{Conclusions}

In recent decades, there have been dramatic changes in house prices in Spain (both positive and negative), often fostered by public authorities at the local, regional, or even national level [44]. Changes in zoning and land use regulations in 1997 and 1998, an oversized construction sector, weak lending standards (loan-to-value ratios close to $100 \%$ in many cases) particularly in regional banks controlled by local political elites [45], growing demand due to the increase in the population (both nationals and foreigners, particularly in tourist regions), and the speculative behavior of some institutional and private buyers also helped to sustain the growth in house prices, housing stock, urban space, and mortgage loans [46]. Our results revealed that the housing boom and subsequent crash in Spain had significant consequences on family formation. Therefore, public authorities should try to reduce fluctuations in house prices in the future to avoid similar episodes, because we might expect that, if episodes of fast-rising house prices are repeated, marriage figures and fertility rates will decline [8]. Nevertheless, although marriage is one of the ways house prices can affect fertility decisions, further research is needed to explicitly analyze the direct link between house prices and births $[22,47,48]$.

Finally, our results strongly depend on the datasets used (explicitly, on the period considered) and on the model specification considered. Further research varying either of these two features could generate new findings. We propose two future lines of research. First, the use of microdata could provide strong validation of the empirical relationship between house prices and marriage. In this paper, we considered aggregate data (at the regional and local levels), whereas many other studies typically considered survey data [16-21]. Moreover, the period examined (1995-2018) includes an important housing bubble in the Spanish housing market, so we might wonder whether the observed link would remain significant during a period with a smoother evolution of prices.

Second, the empirical models used are linear models, but some authors speculate about possible asymmetries in the response of marriage to change in house prices, depending on the initial level of the price [29]. To overcome the limitations of traditional linear approaches, 
the use of semiparametric methods is recommended [49]. This alternative approach would allow us to tackle the possible nonlinear effect of initial house prices on marriage in a flexible way because the model is a mixture of both parametric and nonparametric regressions. An alternative methodology could be the use of threshold regressions [29]. These nonlinear methods could provide a more accurate fit to the relationship between house prices and marriage.

Funding: This research was funded by Fundación Ramón Areces, "XVIII Concurso Nacional para la Adjudicación de Ayudas a la Investigación en Ciencias Sociales". The author also acknowledges the financial support of the Spanish Ministerio de Ciencia e Innovación (projects ECO2017-82246-P and PID2020-114354RA-I00), DGA (ADETRE research group), and ERDF.

Institutional Review Board Statement: Not applicable.

Informed Consent Statement: Not applicable.

Data Availability Statement: Data used in this study are publicly available to download from the webpages of the Instituto Nacional de Estadística (www.ine.es), the Ministerio de Fomento (www.fomento. gob.es) and Fundación Bancaja \& Ivie (Instituto Valenciano de Investigaciones Económicas, www.ivie.es), accessed on 14 April 2021.

Conflicts of Interest: The author declares no conflict of interest.

\section{Appendix A}

In this Appendix, we show the descriptive statistics of the variables used in the empirical analysis.

Table A1. Descriptive statistics.

\begin{tabular}{ccccc}
\hline Variable & Mean & $\begin{array}{c}\text { Standard } \\
\text { Deviation }\end{array}$ & Minimum & Maximum \\
\hline Marriage rate (regional data) & 4.073 & 0.885 & 2.042 & 6.226 \\
Marriage rate (local data) & 3.895 & 1.019 & 0.598 & 9.820 \\
House price (regional data) & 1162.902 & 520.708 & 383.2 & 3045.6 \\
House price (local data) & 1580.679 & 660.446 & 519.575 & 3899.4 \\
Regional unemployment rate & 16.395 & 7.794 & 2.996 & 42.303 \\
Regional inflation rate & 2.299 & 1.517 & -1.575 & 5.908 \\
Regional \% female population & 20.352 & 7.476 & 5.722 & 54.316 \\
with some college & & & & \\
\hline
\end{tabular}

Notes: Marriage rate is the number of marriages per 1000 population. House prices in EUR per $\mathrm{m}^{2}$.

\section{References}

1. Gholipour, H.F.; Farzanegan, M.R. Marriage crisis and housing costs: Empirical evidence from provinces of Iran. J. Policy Modeling 2015, 37, 107-123. [CrossRef]

2. Grossbard-Schectman, S. On the Economics of Marriage; Routledge: New York, NY, USA, 2019.

3. Becker, G.S. A theory of marriage: Part I. J. Political Econ. 1973, 81, 813-846. [CrossRef]

4. Shore, S.H. For better, for worse: Intra-household risk-sharing over the business cycle. Rev. Econ. Stat. 2009, 92, 536-548. [CrossRef]

5. Stevenson, B.; Wolfers, J. Marriage and divorce: Changes and their driving forces. J. Econ. Perspect. 2007, 21, 27-52. [CrossRef]

6. Grossbard, S. The Marriage Motive: A Price Theory of Marriage: How Marriage Markets Affect Employment, Consumption, and Savings; Springer: New York, NY, USA, 2015.

7. Langlais, E. On unilateral divorce and the "selection of marriages" hypothesis. Louvain Econ. Rev. 2010, 76, 229-256. [CrossRef]

8. Ahn, N.; Mira, P. Job Bust, Baby Bust?: Evidence from Spain. J. Popul. Econ. 2001, 14, 505-521. [CrossRef]

9. Parreño Castellano, J.M.; Domínguez Mujica, J.; Armengol Martín, M.T.; Boldú Hernández, J.; Pérez García, T. Real estate dispossession and evictions in Spain: A theoretical geographical approach. Boletín Asoc. Geógrafos Españoles 2019, 80, 2602. [CrossRef]

10. Romero, J.; Jiménez, F.; Villoria, M. (Un)sustainable territories: Causes of the speculative bubble in Spain (1996-2010) and its territorial, environmental, and sociopolitical consequences. Environ. Plan. C Gov. Policy 2012, 30, 467-486. [CrossRef] 
11. Blanco, F.; Martín, V.; Vazquez, G. Regional house price convergence in Spain during the housing boom. Urban Stud. 2016, 53, 775-798. [CrossRef]

12. Ogburn, W.F.; Thomas, D.S. The influence of the business cycle on certain social conditions. J. Am. Stat. Assoc. 1922, 18, 324-340. [CrossRef]

13. Stouffer, S.A.; Spencer, L.M. Marriage and divorce in recent years. Ann. Am. Acad. Political Soc. Sci. 1936, 188, 56-69. [CrossRef]

14. Silver, M. Births, marriages, and business cycles in the United States. J. Political Econ. 1965, 73, 237-255. [CrossRef]

15. Browning, M.; Chiappori, P.-A.; Weiss, Y. Economics of the Family; Cambridge University Press: Cambridge, NY, USA, 2014.

16. Borsch-Supan, A. Household formation, housing prices, and public policy impacts. J. Public Econ. 1986, 30, 145-164. [CrossRef]

17. Edin, K.; Reed, J. Why don't they just get married? Barriers to marriage amongst the disadvantaged. Future Child. 2005, 15, 117-137. [CrossRef]

18. Wrenn, D.H.; Yi, J.; Zhang, B. House prices and marriage entry in China. Reg. Sci. Urban Econ. 2019, 74, 118-130. [CrossRef]

19. Hu, M.; Wu, L.; Xiang, G.; Zhong, S. Housing prices and the probability of marriage among the young: Evidence from land reform in China. Int. J. Emerg. Mark. 2021. [CrossRef]

20. Ermisch, J.; Di Salvo, P. The economic determinants of young people's household formation. Economica 1997, 64, 627-644. [CrossRef]

21. Haurin, D.R.; Hendershott, P.H.; Kim, D. The impact of real rents and wages on household formation. Rev. Econ. Stat. 1993, 75, 284-293. [CrossRef]

22. Mulder, C.H.; Billari, F.C. Homeownership regimes and low fertility. Hous. Stud. 2010, 25, 527-541. [CrossRef]

23. Clark, W.A.V.; Deurloo, M.C.; Dieleman, F.M. Tenure changes in the context of micro level family and macro level economic shifts. Urban Stud. 1994, 31, 137-154. [CrossRef]

24. Clark, W.A.V.; Dieleman, F.M. Households and Housing: Choice and Outcomes in the Housing Market; Centre for Urban Policy Research: New Brunswick, NJ, USA, 1996.

25. Kendig, H.L. Housing careers, life cycle and residential mobility: Implications for the housing market. Urban Stud. 1984, 21, 271-283. [CrossRef]

26. Montgomery, M. Household formation and home-ownership in France. In Demographic Applications of Event History Analysis; Trussell, J., Hankinson, R., Tilton, J., Eds.; Clarendon Press: Oxford, UK, 1992; pp. 94-119.

27. Feijten, P.; Mulder, C.H. The timing of household events and housing events in the Netherlands: A longitudinal perspective. Hous. Stud. 2002, 17, 773-792. [CrossRef]

28. Mulder, C.H.; Wagner, M. First-time home-ownership in the family life course: A West German-Dutch comparison. Urban Stud. 1998, 35, 687-713. [CrossRef]

29. Su, C.-W.; Khan, K.; Hao, L.-N.; Tao, R.; Dumitrescu Peculea, A. Do house prices squeeze marriages in China? Econ. Res.-Ekon. Istraživanja 2020, 33, 1419-1440. [CrossRef]

30. Martín, A.; Moral-Benito, E.; Schmitz, T. The Financial Transmission of Housing Bubbles: Evidence from Spain. American Economic Review 2021, 111, 1013-1053. [CrossRef]

31. Weiss, Y. The formation and dissolution of families: Why marry? Who marries whom? And what happens upon divorce. Handb. Popul. Fam. Econ. 1997, 1, 81-123.

32. Yi, J.; Zhang, J. The effect of house price on fertility: Evidence from Hong Kong. Econ. Inq. 2009, 48, 635-650. [CrossRef]

33. Ruzhi, X.U.; Khan, K.; Moldovan, N.C.; Iosif, A. Do house prices and marriages move together in China? Econ. Comput. Econ. Cybern. Stud. Res. 2019, 53, 59-78. [CrossRef]

34. Easterlin, R.A. Birth and Fortune: The Impact of Numbers on Personal Welfare; Basic Books: New York, NY, USA, 1980.

35. Hughes, M.E. What Money Can Buy: The Relationship between Marriage and Home Ownership in the United States; Duke University: Durham, NC, USA, 2004.

36. González-Val, R.; Marcén, M. Unemployment, Marriage and Divorce. Appl. Econ. 2018, 50, 1495-1508. [CrossRef]

37. Schellekens, J.; Gliksberg, D. Inflation and Marriage in Israel. J. Fam. Hist. 2013, 38, 78-93. [CrossRef]

38. Lopez, C.; Papell, D.H. Convergence of Euro area inflation rates. J. Int. Money Financ. 2012, 31, 1440-1458. [CrossRef]

39. Torr, B.M. The Changing Relationship between Education and Marriage in the United States, 1940-2000. J. Fam. Hist. 2011, 36, 483-503. [CrossRef] [PubMed]

40. Gutiérrez-Domènech, M. The impact of the labour market on the timing of marriage and births in Spain. J. Popul. Econ. 2008, 21, 83-110. [CrossRef]

41. Connolly, M. Some like it mild and not too wet: The influence of weather on subjective well-being. J. Happiness Stud. 2013, 14, 457-473. [CrossRef]

42. Arellano, M.; Bond, S. Some tests of specification for panel data: Monte Carlo evidence and an application to employment equations. Rev. Econ. Stud. 1991, 58, 277-297. [CrossRef]

43. Méndez, R. Ciudades en Venta; PUV Universitat de València: Valencia, Spain, 2019.

44. González-Val, R. The effects of the 2012 Spanish law reform to protect mortgage debtors. Hous. Policy Debate 2021, 31, 239-253. [CrossRef]

45. Akin, O.; Montalvo, J.; Villar, J.G.; Peydró, J.-L.; Raya, J. The real estate and credit bubble: Evidence from Spain. SERIEs-J. Span. Econ. Assoc. 2014, 5, 223-243. [CrossRef] 
46. García, M. The breakdown of the Spanish urban growth model: Social and territorial effects of the global crisis. Int. J. Urban Reg. Res. 2010, 34, 967-980. [CrossRef]

47. Clark, W.A.V. Do women delay family formation in expensive housing markets? Demogr. Res. 2012, 27, 1-24. [CrossRef]

48. Enström Öst, C. Housing and children: Simultaneous decisions?-A cohort study of young adults' housing and family formation decision. J. Popul. Econ. 2011, 25, 349-366.

49. Durlauf, S.N. Manifesto for a growth econometrics. J. Econom. 2001, 100, 65-69. [CrossRef] 